\title{
Taxonomic Classification of Anoxybacillus Isolates from Geothermal Regions in Turkey by $16 S$ rRNA Gene Sequences and ARDRA, ITS-PCR, Rep-PCR Analyses
}

\author{
ARZU COLERI CIHAN* \\ Ankara University, Faculty of Science, Biology Department, 06100, Tandogan, Ankara, Turkey \\ Received 9 January 2013, accepted 8 February 2013
}

\begin{abstract}
A total of 115 endospore-forming bacilli were taken for 16S rRNA gene sequence analyses and clustered among 7 genera. In this paper, the most abundant thermophiles belonging to genus Anoxybacillus with its 53 isolates are presented. The Anoxybacillus species, some of which were producing biotechnologically valuable enzymes, mostly displayed amylolytic and glucosidic activities and the ability of carbohydrate degradation made them superior in number among the other bacilli in these extreme habitats. In comparative sequence analyses, similarities ranged from $91.1 \%$ to $99.9 \%$ between the isolates and the type strains. Isolates were clustered into eight phylogenetic lineages within the type strains of A. kamchatkensis, A. flavithermus, A. kamchatchensis subsp. asaccharedens, and A. salavatliensis. In addition, C161ab and A321 were proposed as novel species which displayed $<97.0 \%$ similarities to their closest relatives. Moreover, their individual AluI, HaeIII, and TaqI ARDRA restriction patterns, ITS-, (GTG) --, and BOX-PCR fingerprintings generated 27, 28, 31, 35, 40, and 41 clusters, respectively. The twelve type strains and 35 of the isolates showed unique distinctive patterns from all the others at least in two of these analyses. These phenotypic and genomic characters allowed us to differentiate their genotypic diversity from the reference strains.
\end{abstract}

Ke y word s: Anoxybacillus, isolation, thermophilic, 16S rRNA gene, ARDRA, ITS- and Rep-PCR

\section{Introduction}

Although the genus Anoxybacillus contains the endospore-forming, thermophilic rod shaped bacteria which are close to the genus Bacillus, they have only been described recently by Pikuta et al. (Pikuta et al., 2000; 2003). Since then, the number of Anoxybacillus species of which this genus is comprised has rapidly increased and now contains the following nineteen validly described species and 3 subspecies: Anoxybacillus pushchinoensis, Anoxybacillus flavithermus (Pikuta et al., 2000), Anoxybacillus gonensis (Belduz et al., 2003), Anoxybacillus contaminans (De Clerck etal., 2004) Anoxybacillus voinovskiensis (Yumoto et al., 2004), Anoxybacillus kestanbolensis, Anoxybacillus ayderensis (Dulger etal., 2004), Anoxybacillus kamchatkensis (Kevbrin et al., 2005), Anoxybacillus amylolyticus (Poli et al., 2006), Anoxybacillus rupiensis (Derekova et al., 2007), Anoxybacillus bogrovensis (Atanassova et al., 2008), Anoxybacillus kamchatkensis subsp. asaccharedens (Gul-Guven et al., 2008), Anoxybacillus thermarum (Poli et al., 2009), Anoxybacillus eryuanensis, Anoxybacillus tengchongensis (Zhang et al., 2010), Anoxybacillus salavatliensis (Cihan et al., 2011), Anoxybacillus mongoliensis (Namsaraev et al., 2010), Anoxybacillus flavithermus subsp. flavithermus, Anoxybacillus flavithermus subsp. yunnanensis (Dai et al., 2011), Anoxybacillus caldiproteolyticus (Coorevits et al., 2012), Anoxybacillus tepidamans (Schäffer et al., 2004; Coorevits et al., 2012), and Anoxybacillus kaynarcensis (Inan et al., 2012). Of those from these species, A. kaynarcensis and A. kamchatkensis subsp. asaccharedens are still not included in the validation list. In addition, most of the species belonging to genus Anoxybacillus were phylogenetically found to be a homogeneous group of thermophilic bacilli with high $16 \mathrm{~S}$ rRNA gene sequence similarity values. Moreover the species from genus Anoxybacillus were aerotolerant anaerobes or facultative anaerobes as can be deduced from the genus name, but Anoxybacillus name means small rod living without oxygen (Pikuta et al., 2000). Pikuta et al. (2000) first described the type strain of this genus as obligate anaerobe, later on Pikuta et al. (2003) presented a note to correct the description of the species A. pushchinoensis from obligate anaerobe to aerotolerant anaerobe and changed the description of the genus Anoxybacillus from obligate anaerobes to

\footnotetext{
* Corresponding author: A.C. Cihan, Ankara University, Faculty of Science, Biology Department, 06100, Tandogan, Ankara, Turkey; phone: +90 312 2126720/1095; fax: +90 312 2232395; e-mail: arzucoleri@gmail.com, acihan@science.ankara.edu.tr
} 
facultative anaerobes or aerotolerant anaerobes or facultative anaerobes.

Furthermore, isolation of novel thermophilic bacilli has received considerable attention since they include species of industrial, biotechnological and environmental interest. These thermozymes have been used in a number of industrial applications as they possess thermal stability to harsh industrial processes at high temperatures (Demirjian etal., 2001). Thermophilic bacilli are the natural source of many thermostable enzymes, and of those from thermophilic bacilli, some thermostable enzymes belonging to species from the genus Anoxybacillus such as amylase (Poli et al., 2006), glucosidase (Cihan et al., 2009), esterase (Colak et al., 2005), aldolase (Ertunga et al., 2007), proteinase (Lavrenteva et al., 2009) and xylanase (Kacagan et al., 2008) have been well characterized.

In this context, a polyphasic approach has been taking attention not only in microbial ecological researches in order to screen isolates producing novel thermostable enzymes that could suggest new applications (Derekova et al., 2008), but also in taxonomic studies when determining the phenotypic and genotypic diversity of these microorganisms, placing some of these bacilli in appropriate taxonomic levels, and also when characterizing novel species from these natural thermal habitats harbouring undiscovered microorganisms (Mora et al., 1998). This approach clusters a great number of similar bacteria belonging to the same genus and includes obtaining information about these clusters with definitive phenotypic and DNA-directed genotypic fingerprinting methods such as amplified ribosomal DNA restriction analysis (ARDRA) PCR reactions of intergenic transcribed spacers (ITS-PCR), and the repetitive extragenic palindromic elements (Rep-PCR) (Mora et al., 1998; Vaneechoutte et al., 1992; White et al., 1993).

Turkey is rich in geothermal sources which vary in typical temperatures and $\mathrm{pH}$ values and these environments have not yet been thoroughly studied. In the present study, the phylogenetic diversity of the isolates from genus Anoxybacillus was characterized and their taxonomic levels were determined by a polyphasic approach, all of which were isolated from geothermal areas in Turkey. Isolates were also screened for their amylolytic, glucosidic and proteolytic activities which might have biotechnological potential. The taxonomic data of these bacilli presented in this research were derived from the phenotypic characteristics, $16 \mathrm{~S}$ rRNA gene sequences, ARDRA, ITS-PCR and Rep-PCR patterns. Therefore, this study is the first report which contains comprehensive phenotypic and genotypic data derived from a great number of Anoxybacillus isolates, all of which were obtained from wide geothermal regions in Turkey.

\section{Experimental}

Material and Methods

Sampling, isolation and growth conditions. During a previous polyphasic taxonomic study, more than five hundred thermophilic bacilli were isolated from different geothermal regions of Turkey (Coleri etal., 2009). In this study, 115 of the former isolates were randomly selected and taken into $16 \mathrm{~S}$ rRNA gene sequence analyses and of those from the isolates only species belonging to genus Anoxybacillus are presented in the paper. The sampling, isolation and growth conditions of the isolates used in this study were as follows: A total of 108 samples including water (10), sediment (40), soil (55), stone (1) and tree branch (2) specimens were collected aseptically from 10 hot springs and 9 high-temperature well pipelines located in two geographically separated areas in Turkey: Aegean Region and Middle Anatolian Region. Of those geothermal regions, Aydin (Region A; 2751' E, 37 $51^{\prime} \mathrm{N}$ ), Denizli (Region C; $29^{\circ} 06^{\prime} \mathrm{E}, 37^{\circ} 46^{\prime} \mathrm{N}$ ) and Izmir (Region D; $27^{\circ} 09^{\prime} \mathrm{E}, 38^{\circ} 25^{\prime} \mathrm{N}$ ) provinces are in the Aegean Region, whereas Nevsehir (Region E; 34 $43^{\prime} \mathrm{E}, 38^{\circ} 38^{\prime} \mathrm{N}$ ) and Ankara (Region F; 3252' E, 39 $56^{\circ} \mathrm{N}$ ) provinces are located in the Middle Anatolian Region of Turkey. The water temperature and $\mathrm{pH}$ of these geothermal areas were between $50-100^{\circ} \mathrm{C}$ and $6.0-9.0$, respectively.

One $\mathrm{ml}$ water and sediment sample or approximately $1 \mathrm{~g}$ soil, stone, and tree branch sample from each place was incubated in $5 \mathrm{ml}$ of the MI medium containing $1 \%$ soluble starch $(\mathrm{pH} 7.0)$ at $60^{\circ} \mathrm{C}$ with $250 \mathrm{rpm}$ shaking for $24 \mathrm{~h}$ to obtain the enrichment culture, after each sample was heat-treated at $80^{\circ} \mathrm{C}$ for $10 \mathrm{~min}$ to kill vegetative cells (Coleri et al., 2009; Suzuki et al., 1976). The turbid enrichments were streaked on plates of $\mathrm{MI}$ containing $3 \%$ agar and incubated aerobically at $60^{\circ} \mathrm{C}$ for $24-48 \mathrm{~h}$. The single colonies having different colony morphology were then picked and sub-cultured at least three times until a pure culture was obtained. The cell morphologies of the isolates were also examined by phase contrast microscopic observation. All of the isolates were routinely maintained at $4^{\circ} \mathrm{C}$ on $\mathrm{MI}$ agar slants and stored at $-80^{\circ} \mathrm{C}$ in $\mathrm{MI}$ broth cultures supplemented with $20 \%$ glycerol.

Isolates were designated according to their geothermal area of origin, the sample number taken from that origin and the number of the isolates obtained in that sample. The designation of the 53 isolates, their geothermal areas of origin and the reference strains used in this study are presented in Table I.

Morphologic and physiologic characterization. MI medium was preferred to Nutrient Agar in general incubation and morphological studies as it enabled a better growth of all these isolates aerobically or anaerobically 
Table I

Diversity and origin of the Anoxybacillus isolates from different geothermal regions of Turkey and the reference strains used in this study.

\begin{tabular}{|c|c|c|}
\hline Bacterial isolates & Origin & $\begin{array}{l}\text { Number } \\
\text { of bacteria }\end{array}$ \\
\hline $\mathrm{A} 321^{\mathrm{a}}, \mathrm{A} 3210^{\mathrm{a}}$ & Omerbeyli, Germencik, Aydin, Turkey & 2 \\
\hline $\mathrm{A} 351 \mathrm{a}^{\mathrm{b}}, \mathrm{A} 352 \mathrm{~b}^{\mathrm{b}}, \mathrm{A} 371^{\mathrm{a}}, \mathrm{A} 402 \mathrm{~b}^{\mathrm{a}}, \mathrm{A} 414^{\mathrm{a}}$ & Yavuzkoy, Salavatli, Aydin, Turkey & 5 \\
\hline $\mathrm{C} 161 \mathrm{ab}^{\mathrm{a}}, \mathrm{C} 163 \mathrm{a}^{\mathrm{a}}, \mathrm{C} 245^{\mathrm{a}}$ & Buharkent,Tekkehamam/Tekkekoy, Denizli, Turkey & 3 \\
\hline D36 $6^{\mathrm{b}}, \mathrm{D} 98 \mathrm{a}^{\mathrm{a}}$ & Balcova Geothermal Site, Izmir, Turkey & 2 \\
\hline $\mathrm{D}^{2} \mathrm{~b}^{\mathrm{b}}$ & Seferhisar, Urkmez, Izmir, Turkey & 1 \\
\hline 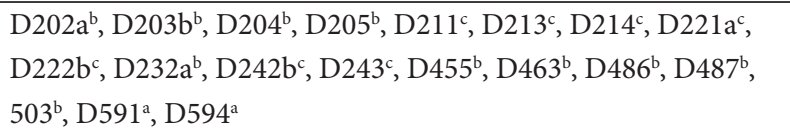 & Dikili, Kaynarca, Kocaoba, İzmir, Turkey & 19 \\
\hline D371 $a^{b}, D 376 b^{b}, D 392^{a}, D 394^{a}, D 404^{a}, D 433 a^{a}$ & Dikili, Zeytindalı, İzmir, Turkey & 6 \\
\hline $\mathrm{D}^{2} 01 \mathrm{a}^{\mathrm{a}}$ & Dikili, Camur Hot Spring, Izmir, Turkey & 1 \\
\hline $\mathrm{E} 123^{\mathrm{b}}, \mathrm{E} 237^{\mathrm{b}}, \mathrm{E} 243^{\mathrm{b}}, \mathrm{E} 272^{\mathrm{b}}, \mathrm{E} 331^{\mathrm{d}}$ & Altinsu, Kozakli, Nevsehir, Turkey & 5 \\
\hline $\begin{array}{l}\mathrm{E} 183^{\mathrm{a}}, \mathrm{E} 184 \mathrm{aa}^{\mathrm{a}}, \mathrm{E} 184 \mathrm{ab}^{\mathrm{a}}, \mathrm{E} 184 \mathrm{~b}^{\mathrm{a}}, \mathrm{E} 187^{\mathrm{a}}, \mathrm{E} 206 \mathrm{a}^{\mathrm{a}}, \mathrm{E} 206 \mathrm{~b}^{\mathrm{a}}, \mathrm{E} 208 \mathrm{a}^{\mathrm{a}}, \\
\mathrm{E} 208 \mathrm{~b}^{\mathrm{a}}\end{array}$ & Baglica Kozakli, Nevsehir, Turkey & 8 \\
\hline $\mathrm{F} 81^{\mathrm{e}}$ & Kizilcahamam, Ankara, Turkey & 1 \\
\hline Total number of the bacterial isolates & & 53 \\
\hline \multicolumn{3}{|l|}{ Reference strains } \\
\hline Anoxybacillus flavithermus DSM $2641^{\mathrm{T}}$ & Kindly provided by Prof. A. O. Belduz & \\
\hline Anoxybacillus kestanbolensis NCIB $13971^{\mathrm{T}}$ & Kindly provided by Prof. A. O. Belduz & \\
\hline Anoxybacillus gonensis NCIB $13933^{\mathrm{T}}$ & Kindly provided by Prof. A. O. Belduz & \\
\hline Anoxybacillus ayderensis NCIB $13972^{\mathrm{T}}$ & Kindly provided by Prof. A. O. Belduz & \\
\hline Anoxybacillus pushchinoensis DSM $12423^{\mathrm{T}}$ & DSMZ & \\
\hline Anoxybacillus thermarum DSM $17141^{\mathrm{T}}$ & DSMZ & \\
\hline Anoxybacillus kamchatkensis DSM $14988^{\mathrm{T}}$ & DSMZ & \\
\hline Anoxybacillus amylolyticus DSM $15939^{\mathrm{T}}$ & DSMZ & \\
\hline Anoxybacillus rupiensis DSM $17127^{\mathrm{T}}$ & DSMZ & \\
\hline Anoxybacillus voinovskiensis DSM $17075^{\mathrm{T}}$ & DSMZ & \\
\hline Anoxybacillus tepidamans DSM $16325^{\mathrm{T}}$ & DSMZ & \\
\hline Anoxybacillus thermarum DSM $17141^{\mathrm{T}}$ & DSMZ & \\
\hline Anoxybacillus salavatliensis DSM $22626^{\mathrm{T}}$ & From our collection & \\
\hline Total number of the reference strains & & 13 \\
\hline
\end{tabular}

${ }^{a}$ - soil sample, ${ }^{b}$ - sediment sample, ${ }^{\mathrm{c}}$ - water sample, ${ }^{\mathrm{d}}$ - branch of a tree, ${ }^{\mathrm{e}}-$ stone sample.

on plates. Thus, the temperature range was determined by incubating the strains in $\mathrm{MI}$ at temperatures from 20 to $80^{\circ} \mathrm{C}$ for $24-72 \mathrm{~h}$. The cell morphology, motility and spore formation were observed with freshly prepared wet mounts using phase-contrast microscopy. The active cultures grown in MI Broth at $60^{\circ} \mathrm{C}$ under shaking for $18-24 \mathrm{~h}$ were used when describing the cell morphology and motility. The formation of spores was also tested by using MI broth cultures of 18-48 h supplemented with $5 \mathrm{mgL}^{-1} \mathrm{MnSO}_{4} \cdot 4 \mathrm{H}_{2} \mathrm{O}$ (Claus and Berkeley, 1986).

The colony morphologies were determined using cultures grown aerobically for all the isolates or anaerobically for $A$. pushchinoensis on MI plates (supplemented with $3 \%$ agar) at $60^{\circ} \mathrm{C}$ for $18-24 \mathrm{~h}$. Gram staining, oxidase and catalase activities were carried out by the methods of Claus and Berkeley as described previously (Claus and Berkeley, 1986). Nine reference strains were used as control groups in all the phenotypic and genotypic characterization tests. All the phenotypic characters were carried out in triplicates.

Enzyme assays. All of the isolates were screened for their amylase, a-glucosidase and protease activities qualitatively on agar plates. Amylolytic activity was tested on MI agar plates after incubation for $48 \mathrm{~h}$. Then the plates were treated with iodine solution $(0.2 \%$ $\mathrm{I}_{2}$ in $2 \% \mathrm{KI}$ ) and isolates having starch digestion zones around their colonies were determined as amylolytic (Coleri et al., 2009). When determining a-glucosidase activity, screening was carried out on MI plates by searching para-nitrophenol a-D-glucopyranoside ( $p$ NPG) activity on blotting filter paper as described 
previously (Cihan et al., 2011). The paper disk was incubated at $60^{\circ} \mathrm{C}$ and the yellow colour formation, the colour of which was caused by the reaction of $\alpha$-glucosidase on the substrate, was observed and selected for the positive $a$-glucosidase reaction. In the screening of protease activity, isolates were growth on Skim Milk Agar ( $\mathrm{pH}$ 7.0) plates for $72 \mathrm{~h}$ (Tekin et al., 2012). Protease producing isolates which gave a clear zone around their colonies due to the hydrolysis of skim milk were selected. The diameters of halo zones and the amount of yellow colour formation were also measured, confirmed and compared with the reference strains which were able to produce these enzymes.

$16 \mathrm{~S}$ rRNA gene amplification and sequencing analyses. Genomic DNA was extracted from the cultures growing on MI medium for $18 \mathrm{~h}$ at $60^{\circ} \mathrm{C}$ by using genomic DNA purification kit (Fermentas). The gene encoding $16 \mathrm{~S}$ rRNA was amplified by PCR with the $16 \mathrm{~S}$ bacteria specific $27 \mathrm{~F}$ forward and the $1492 \mathrm{R}$ reverse primer as described previously (Kuisiene et al., 2002). The amplification products were purified from agarose gel using Gel Extraction Kit (Omega Ezna). The 1000-1500 bp sequences of the PCR-amplified 16S rRNA genes were determined by using ABI 3100 gene sequencer with Bigdye cycle sequencing kit. In the phylogenetic analysis, homology search was carried out using both the basic BLASTN search program at the NCBI web-site and web-based public EzTaxon database (http://eztaxon-e.ezbiocloud.net/), (Kim et al., 2012). Phylogenetic analyses were performed using the maximum-likelihood and neighbour-joining methods with bootstrap values based on 1000 replications. The phylogenetic tree (Saitou and Nei, 1987) was constructed with the MEGA package version 4 (Tamura et al., 2007) and the nucleotide substitution distances were estimated by Jukes-Cantor model (Jukes et al., 1969). As the phylogenetic analyses derived from neighbour-joining method were in congruence with those obtained using the maximum-likelihood algorithm, only the data obtained from the neighbour-joining method is presented in the study.

Amplified ribosomal DNA restriction analysis of $16 S$ rRNA gene. ARDRA analysis of the $16 S$ rRNA gene primed by $27 \mathrm{~F} / 1492 \mathrm{R}$ was carried out on the amplified PCR products by single enzyme digestion, according to the manufacturer's instructions, with Fast digest AluI, HaeIII and TaqI restriction enzymes (MBI Fermentas). The ARDRA profiles of the digested DNA were analyzed by electrophoresis through $2 \%(\mathrm{w} / \mathrm{v})$ agarose gel using $1 \mathrm{X}$ TBE buffer at $120 \mathrm{~V}$ for $1.5 \mathrm{~h}$ (Caccamo et al., 2001). The individual AluI, HaeIII and TaqI ARDRA patterns were analyzed by the GelCompar II software packages (Applied Maths, Belgium). The experimental restriction fragments higher than $45 \mathrm{bp}$ were included in the statistical analysis. Similarities of the digitized profiles were calculated using Dice correlation and an average linkage (UPGMA) dendrogram was obtained for all the restriction analyses. All the restriction analyses and their agarose gel electrophoresis were carried out in triplicates. In addition to experimental restriction analyses, the theoretical AluI, HaeIII and TaqI restriction mapping of the analyzed 16S rRNA gene sequences were also carried out by using an online restriction mapping service (http://restrictionmapper. $\mathrm{org} /$ ). As the experimental results were in relation with theoretical restriction mapping, only the experimental data is presented in this paper.

PCR based fingerprinting analyses of Rep elements and intergenic 16S-23S rRNA gene. Repetitive Elements-PCR (Rep-PCR) genomic fingerprintings were performed with the (GTG) ${ }_{5}$ and BOXA1R primers using the PCR conditions that were described by Versalovic et al. (1994). Primer sets S-D-Bact-1494a-S-20 and L-D-Bact-0035-a-A-15 were used for the amplification of intergenic transcribed spacers (ITS) between $16 \mathrm{~S}$ and $23 \mathrm{~S}$ rRNA genes and PCR conditions were adjusted according to Daffonchio et al. (2003). The PCR products electrophoresed in a 1.5\% agarose gel, using $1 \mathrm{X}$ TBE buffer at $120 \mathrm{~V}$ for $4 \mathrm{~h}$. In the statistical analysis, triplicate individual ITS-PCR, BOXA1 and (GTG) $)_{5}$-PCR fingerprintings were analyzed by the GelCompar II software packages (Applied Maths, Belgium). Similarities of the digitized profiles were calculated using Dice correlation and an average linkage (UPGMA) dendrogram was obtained.

Finally, the individually examined all the ARDRA analyses and the ITS-, (GTG) $)_{5}$ - and BOX-PCR fingerprintings were then taken into a cumulative cluster analysis which combined all these tests in a dendrogram by using the GelCompar II software packages. This combined results containing dendrogram was presented in this paper, instead of showing all the six individual cluster analyses of these fingerprinting tests. In clustering analyses according to the presence or absence of DNA bands and also to their densities, the similarity limits of 16.7, 33.34, 50.0, 66.7 and $83.4 \%$ values were used with GelCompar II software. In these context, the bacteria displaying $0-16.7 \%$ similarities were denoted as having unique distinctive profiles, the ones having similarities between $75.0 \%$ and $99.9 \%$ were determined as showing similar profiles and the ones with 100\% similarity were implied as displaying the same profiles.

GenBank Accession Numbers. The 53 16S rRNA gene sequences presented in this study were obtained from the following Anoxybacillus isolates: A321 (FJ429993), A3210 (FJ429569), A351a (FJ429995), A352b (FJ429996), A371 (FJ430000), A402b (FJ430004), A414 (FJ430007), C161ab (FJ430012), C163a (FJ430013), C245 (FJ430016), D36 (FJ430018), D98a (FJ430021), D202a (FJ430024), D203b 
(FJ430025), D204 (FJ430026), D205 (FJ430027), D211 (FJ430028), D213 (FJ430029), D214 (FJ430030), D221a (FJ430031), D222b (FJ429576), D232a (FJ429577), D242b (FJ429578), D243 (FJ430032), D371a (FJ429580), D376b (FJ430036), D392 (FJ430037), D394 (FJ429581), D401a (FJ430038), D404 (FJ430039), D433a (FJ430041), D455 (FJ429582), D463 (FJ430042), D486 (FJ430043), D487 (FJ430044), D503 (FJ430046), D52b (FJ429575), D591 (FJ430049), D594 (FJ429583), E123 (FJ429584), E183 (FJ430058), E184aa (FJ430059), E184ab (FJ429585), E184b (FJ429586), E206a (FJ430061), E206b (FJ430062), E208a (FJ430063), E208b (FJ429587), E237 (FJ429589), E243 (FJ430064), E272 (FJ429591), E331 (FJ429593), F81 (FJ429595).

\section{Results}

Selection of Anoxybacillus isolates according to the $16 \mathrm{~S}$ rRNA gene sequence analyses. The $16 \mathrm{~S}$ rRNA gene sequences of the 115 aerobic and endospore-forming isolates were analyzed in order to determine their phylogenetic position and to avoid the repeated examination in the same bacterial taxon. All the isolates were phylogenetically clustered on the basis of their individual 16S rRNA gene sequence homologies to their closest relatives. According to the phylogenetic analysis of these sequences, most of the identified isolates from geothermal regions of Turkey fell into Bacillus genetic group 5 along with other thermophilic species. The other isolates clustered in Bacillus genetic group 1 and 3 with their mesophilic and facultative thermophilic counterparts. Comparison of the generated sequences with those in the GenBank database indicated that one hundred and fifteen of them were clustered among the 7 genera: Anoxybacillus (53 isolates), Bacillus (14 isolates), Brevibacillus (12 isolates), Geobacillus (26 isolates), Aeribacillus (4 isolates), Paenibacillus (1 isolates), and Thermoactinomycetes (2 isolates).

The Anoxybacillus isolates used in this study were isolated and purified from 19 geothermal sampling stations located in the Aegean Region and Middle Anatolian Region in Turkey. As indicated above, representatives of the genus Anoxybacillus were predominated among our isolates and $45 \%$ of the isolates were found to be belonged to this genus according to the $16 \mathrm{~S}$ rRNA gene sequence analysis. The $16 \mathrm{~S}$ rRNA gene sequence data of 53 Anoxybacillus isolates have been deposited in the GenBank databases and their accession numbers in relation to the isolates were given in the phylogenetic tree which was obtained using the neighbor-joining method (Fig. 1).

The phylogenetic diversity of Anoxybacillus isolates. The $16 \mathrm{~S}$ rRNA gene sequence analyses in this study contains not only the phylogenetic diversity of our isolates, but also all the described Anoxybacillus species up to now. Thus, all the nineteen described type strains and 3 subspecies from genus Anoxybacillus were taken into comparative sequence analysis as presented in Fig. 1. In comparison analyses, all the members of genus Anoxybacillus listed in the introduction section, shared 16S rRNA gene sequence similarities from 93.8 to $99.9 \%$. Furthermore, species of A. flavithermus DSM $2641^{\mathrm{T}}$, A. salavatliensis DSM $22626^{\mathrm{T}}$, A. gonensis NCIMB 13933', A. ayderensis NCIMB 13972' ${ }^{\mathrm{T}}$ A. kestanbolensis NCIB $13971^{\mathrm{T}}$, A. thermarum DSM $17141^{\mathrm{T}}$, A. kamchatkensis DSM $14988^{\mathrm{T}}$, A. kamchatkensis subsp. asaccharedens DSM $18475^{\mathrm{T}}$, A.eryuanensis KCTC $13720^{\mathrm{T}}$, A.tengchongensis KCTC $13721^{\mathrm{T}}$, A.pushchinoensis DSM 12423 $3^{\mathrm{T}}$, A.mongoliensis DSM $19169^{\mathrm{T}}$, A. flavithermus subsp. flavithermus BCRC $17265^{\mathrm{T}}$, A. flavithermus subsp. yunnanensis KCTC $13759^{\mathrm{T}}$, and A. kaynarcensis DSM $21706^{\mathrm{T}}$ showed $16 \mathrm{~S}$ rRNA gene sequence similarities from $97.4 \%$ to $99.9 \%$. These strains were genetically found to be very homogeneous and be able to be differed from each other only by DNA-DNA hybridization analyses. Moreover, the rest of the Anoxybacillus species such as A. bogrovensis DSM $17956^{\mathrm{T}}$ A. rupiensis DSM $17127^{\mathrm{T}}$, A. contaminans DSM $15866^{\mathrm{T}}$, A. voinovskiensis DSM $17075^{\mathrm{T}}$, A. amylolyticus DSM 15939 ${ }^{\mathrm{T}}$, A.tepidamans DSM $16325^{\mathrm{T}}$ and A.caldiproteolyticus DSM $15730^{\mathrm{T}}$ displayed a more heterogenic sequence homology with each other (from $93.9 \%$ to $99.6 \%$ ) and formed distinct clusters in sequence comparisons.

According to the 16S rRNA gene sequence analysis, 53 of the isolates were found to belong to the genus Anoxybacillus as shown in the phylogenetic tree in Fig. 1. The sequence similarity values determined between the Anoxybacillus isolates and the recognized Anoxybacillus type strains were ranged from 91.1\% to $99.9 \%$. In addition, the sequence similarity values from $90.8 \%$ to $99.9 \%$ were determined between the Anoxybacillus isolates. Although most of the isolates had sequence similarity values higher than $97.0 \%$ to more than one closest relatives, the sequence comparison analyses given below were determined according to their most closely related type strains. According to these results, Anoxybacillus isolates branched within the phylogenetically homogenous Anoxybacillus type strains mentioned before. The clusters obtained from the 16S rRNA gene sequence analyses, the similarity values of the Anoxybacillus isolates to their closest relative(s) and content of these clusters were also presented in Table II.

The most abundant species was A.salavatliensis and this species was diverted into two groups. Cluster 1 was consisted of 8 isolates with sequence similarity values of $96.0-98.1 \%$ to A. salavatliensis, but although A321 isolate was branched within the A. salavatliensis 


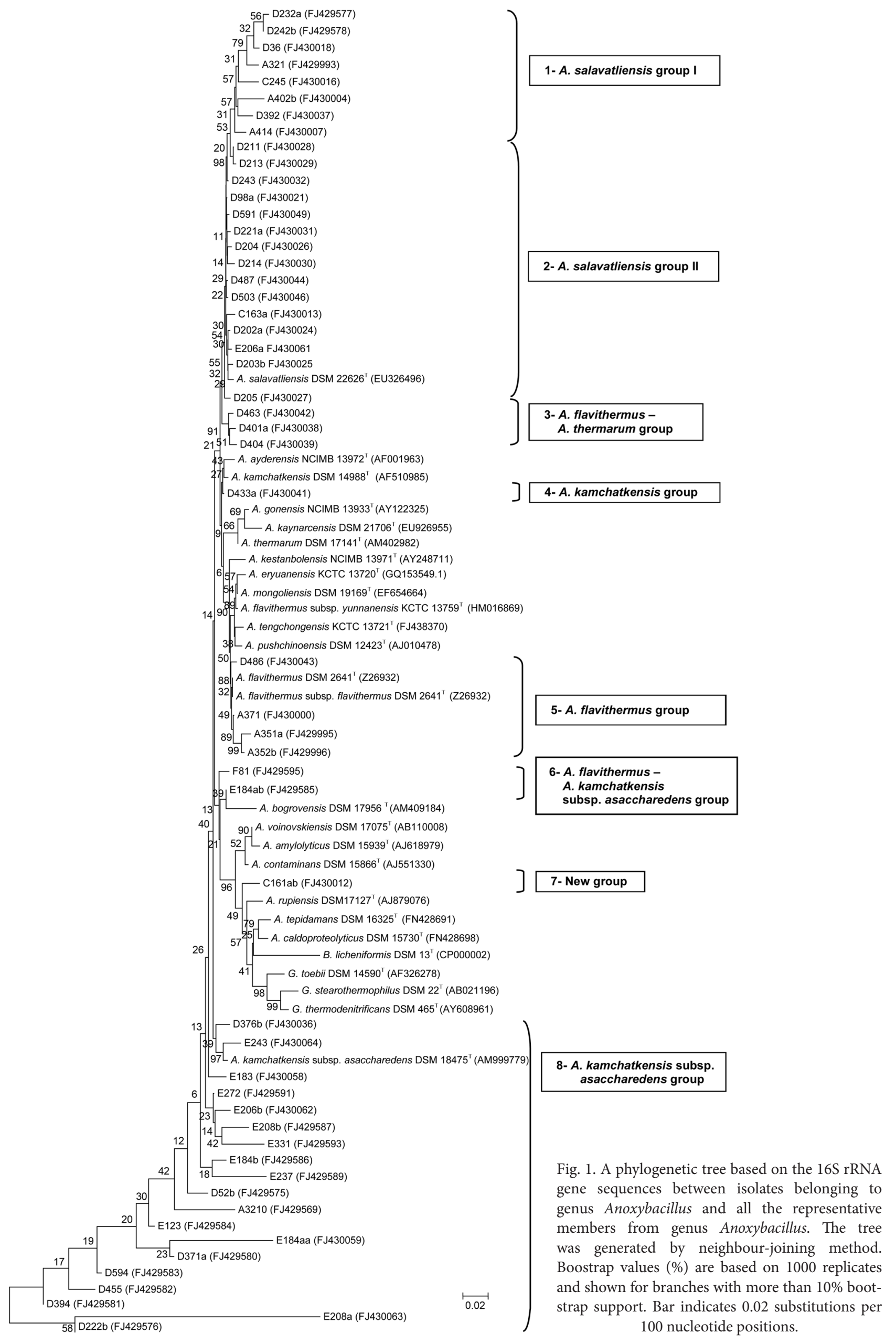


Table II

The 16S rRNA gene sequence similarities of the 53 Anoxybacillus isolates to their closest relative(s)

\begin{tabular}{|c|c|c|c|}
\hline \multicolumn{4}{|c|}{ According to $16 \mathrm{~S}$ rRNA gene sequences } \\
\hline \multicolumn{2}{|r|}{ The closest relative(s) } & $\begin{array}{l}\text { Similarities to the } \\
\text { closest relative(s) }\end{array}$ & Contents of the phylogenetic clusters \\
\hline 1 & A. salavatliensis DSM $22626^{\mathrm{T}}$ & $96.0-98.1 \%$ & D232a, D242b, A414, D392, C245, A402b, D36, A321 \\
\hline 2 & A. salavatliensis DSM $22626^{\mathrm{T}}$ & $98.5-99.8 \%$ & $\begin{array}{l}\text { D204, D221a, D98a, D202a, D243, D487, E208a, D203b, } \\
\text { D503, D591, D205, C163a, D211, D213, D214 }\end{array}$ \\
\hline 3 & A. flavithermus DSM $2641^{\mathrm{T}}$ & $98.8-98.9 \%$ & \multirow{2}{*}{ D463, D401, D404 } \\
\hline & A. thermarum DSM $17141^{\mathrm{T}}$ & $98.6-98.8 \%$ & \\
\hline 4 & A. kamchatkensis DSM $14988^{\mathrm{T}}$ & $99.6 \%$ & D433a \\
\hline 5 & A. flavithermus DSM $2641^{\mathrm{T}}$ & $98.5-99.7 \%$ & A371, D486, A352b, A351a \\
\hline 6 & A. flavithermus DSM $2641^{\mathrm{T}}$ & $98.2-99.3 \%$ & \multirow{2}{*}{ E184ab, F81 } \\
\hline & A. kamchatkensis subsp. asaccharedens DSM $18475^{\mathrm{T}}$ & $98.4-99.5 \%$ & \\
\hline 7 & $\begin{array}{l}\text { A. rupiensis DSM } 17127^{\mathrm{T}} \\
\text { A. voinovskiensis DSM } 17075^{\mathrm{T}} \\
\text { A. caldoproteolyticus DSM } 15730^{\mathrm{T}}\end{array}$ & $96.8-96.9 \%$ to all & C161ab \\
\hline 8 & A. kamchatkensis subsp. asaccharedens DSM $18475^{\mathrm{T}}$ & $97.2-99.7 \%$ & $\begin{array}{l}\text { E208a, E183, E184b , E206b, E243, D222b, E272, D52b, } \\
\text { E123, E237, E208b, E184aa, E331, D594, E123, A3210, } \\
\text { D455, D394 }\end{array}$ \\
\hline
\end{tabular}

Cluster 1, it was not belonged to this type strains as it displayed a similarity value lower than $97 \%$. A321 isolate displayed low similarity values solely to $A$. salavatliensis (96.0\%), A. kamchatkensis (95.8\%), A. kamchatkensis subsp. asaccharedens (95.4\%) and A. flavithermus (95.3\%) among all the described Anoxybacillus type strains. In addition, A321 displayed sequence similarities mostly to D36 (97.1\%), D232a (98.6\%) and D242b (98.6\%) from other non-reference isolates in Cluster 1.

A. salavatliensis Cluster 2 comprised fifteen isolates having more genetic homogeneity not only with each other, but also with their closest relative. The closest relative(s) of the Clusters 3, 4, 5 and 6 were A. flavithermus - A. thermarum, A. kamchatkensis, A. flavithermus, and A. flavithermus - A. kamchatkensis subsp. asaccharedens containing 3, 1, 4 and 2 isolates, respectively.

The Cluster 7 contained only the isolate C161ab, which showed lower similarities than $97.0 \%$ to only $A$. rupiensis (96.9\%), A. voinovskiensis (96.9\%), and A.caldoproteolyticus (96.8\%) from the all described Anoxybacillus type strains. Moreover, C161ab only showed higher than $97 \%$ sequence similarities only to E184ab (98.2\%) and F81 (97.1\%) among the other Anoxybacillus isolates. The 19 isolates comprising Cluster 8 distinguished from all these clusters having sequence similarities between 97.2-99.7\% to their closest relatives A. kamchatkensis subsp. asaccharedens. Among the isolates in these eight clusters, A321 and C161ab represented potentially novel species, sharing less than $97.0 \%$ sequence similarity to their closest relatives.

Phenotypic characteristics of the isolates from genus Anoxybacillus. Colonies of all the Anoxybacil- lus isolates and the reference strains used were usually round and had a yellow pigmentation from pale yellow, yellow or orange yellow as a common character, when incubated on MI Agar plates, except D433a, C161ab and A371 isolates having cream colour colonies. Microscopic observations showed that their cells were mostly Gram-positive staining, motile (except A.pushionensis) and straight rods. Spore formation became detectable after $48-72 \mathrm{~h}$ incubation periods in liquid media. Their cells formed terminal, ellipsoidal to oval or round endospores in a swollen or non swollen sporangia.

The Anoxybacillus isolates and the reference strains were all thermophilic within the growth range between $30^{\circ} \mathrm{C}$ and $73^{\circ} \mathrm{C}$ with an optimal temperature value between 50 to $65^{\circ} \mathrm{C}$. The isolates and the reference strains gave catalase positive reactions instead of A. kamchatkensis and A.pushionensis type strains, and $\mathrm{C} 161 \mathrm{ab}$ isolates. Most of the isolates were able to grow anaerobically, but were facultative anaerobes, except A. pushionensis. In addition, A.rupiensis could only grow strict aerobically. The oxidase reaction varied relationally to the isolate and type strains.

Starch utilization was found to be a dominant character among genus Anoxbacillus except A. kamchatkensis, A. thermarum, and D392. Presence of carbohydrate degrading enzymes such as a-amylase and a-glucosidase was also a common characteristic of isolates and strains from genus Anoxybacillus, instead of A. kamchatkensis and A.thermarum type strains and isolates of D392 and E123. Furthermore, some of the isolates, which thought to have biotechnological potential in industrial applications, exhibited significant 
Table III

Number of clusters of Anoxybacillus isolates and reference strains obtained from individual AluI, HaeIII and TaqI ARDRA profiles of 16S rRNA genes and ITS-, BOX- and GTG-PCR DNA fingerprintings

\begin{tabular}{|l|c|c|c|c|c|c|}
\hline \multirow{2}{*}{ Number of } & \multicolumn{2}{|c|}{ ARDRA profiles of 16S rRNA gene } & \multirow{2}{*}{ ITS-PCR profiles } & \multicolumn{2}{c|}{ Rep-PCR profiles } \\
\cline { 2 - 4 } \cline { 6 - 7 } & AluI & HaeIII & TaqI & & BOX-PCR & GTG-PCR \\
\hline Standard clusters & 8 & 11 & 8 & 12 & 12 & 12 \\
\hline Isolate clusters & 20 & 16 & 23 & 23 & 29 & 28 \\
\hline Total clusters & 28 & 27 & 31 & 35 & 41 & 40 \\
\hline
\end{tabular}

amount of halo zones in amylase assay or produced more yellow colour in a-glucosidase assay, when compared with reference strains and the other isolates. Of those from amylolytic and glucosidic isolates, D323a, D98a, D404, E184aa, E184ab and D222b (6 isolates) had significant amount of amylolytic activity, whereas A414, D211, D213, D202a, D214, D204, E206, A351a, A352b, D3756b, A3210, E272, E208b, E331 and E206b (15 isolates) were capable of producing high levels of a-glucosidase. In addition, only 10 of 53 Anoxybacillus isolates could able to produced halo zones around their colonies in protease assay.

AluI, HaeIII and TaqI-ARDRA analyses of the Anoxybacillus isolates. The amplified PCR products of the isolates from genus Anoxybacillus were subjected to digestion with AluI, HaeIII and TaqI restriction enzymes in comparison with reference strains. The individual AluI-, HaeIII- and TaqI-ARDRA cluster analyses of the digitized banding patterns derived from 53 Anoxybacillus isolates and 12 reference strains can be seen in Fig. 2. The number of clusters obtained from these three ARDRA profiles were shown in Table III, and the content of these individual clusters were indicated in Table IV. The isolates having distinctive patterns in these analyses were also indicated with "*” in Table IV.

In individual cluster analysis based on the AluI-, HaeIII- and TaqI-ARDRA profiles of the amplified $16 \mathrm{~S}$ rRNA genes, totally 28,27 and 31 clusters were observed when the presence or absence of the restriction fragments and also the density of the DNA bands were considered. In AluI-ARDRA analysis, the 12 reference type strains were grouped into 8 clusters and in one of these clusters, A. amyloyticus, A. thermarum, A.salavatliensis, A.gonensis and A.ayderensis type strains formed the same patterns with each other. In addition, only seven of the isolates displayed distinctive patterns from all the isolates and type strains used. In HaeIII- and TaqI-ARDRA analyses, these reference strains formed 11 to 8 clusters, respectively. While the reference strains of A. gonensis and A.rupiensis displayed the same HaeIII-ARDRA patterns, in the case of TaqI-ARDRA analysis A. amylolyticus - A. thermarum, A. ayderensis - A. kestanbolensis and A.flavithermus - A.kamchatkensis - A.gonensis patterns matched with each other and these type strains grouped within three clusters. Beside these findings, 5 to 11 isolates showed unique patterns from all the isolates and reference strains used in HaeIII- and TaqI-ARDRA analyses, respectively. According to these individual cluster analysis of the ARDRA tests, the HaeIII-ARDRA analysis was found to be superior on the other restriction enzyme digestions for differentiating the reference strains within 11 unique clusters, whereas the number of profiles obtained from TaqI-ARDRA analyses was higher than the other restriction patterns, which allowed us to show the difference among all the isolates and reference strains.

The Rep-PCR and ITS-PCR fingerprintings of the Anoxybacillus isolates. All the Anoxybacillus isolates and their related type strains were subjected to the Rep-PCR and ITS fingerprinting analyses. While these fingerprinting results can be seen in Fig. 2, the numbers of the individual clusters and their contents are also presented in Table III and IV. In the individual cluster analyses of the Rep-PCR containing (GTG) ${ }_{5}$ and BOX-PCR fingerprintings, totally 40 to 41 clusters were obtained and any of the isolates showed the same profile with the reference strains. Furthermore, 13 isolates in (GTG) $)_{5}$-PCR and 12 isolates in BOX-PCR showed unique banding patterns from all the others, respectively. In both of these Rep-PCR analyses, all of the reference strains formed unique distinctive patterns from the isolates and from each other.

Not only the Rep-PCR, but also the ITS fingerprinting profiles of these isolates and strains confirmed their genotypic diversity (Fig. 2, Table III and IV). The

Fig. 2. The cumulative cluster analysis of some representative digitized banding patterns, generated by restriction digestions with $A l u \mathrm{I}$, HaeIII and TaqI enzymes of the amplified 16S rRNA genes and by ITS-, BOX- and GTG-PCR profiles from isolates and reference strains belonging to genus Anoxybacillus. The dendrogram was constructed by using UPGMA, with correlation levels expressed as percentage values of the Dice coefficient. The numbers of clusters obtained from the cumulative analysis were indicated in the right side of the figure. The isolates, having unique distinctive profiles, which displayed similarities less than $16.7 \%$ for one to four fingerprintings patterns among these six analyses were indicated with "*”. 


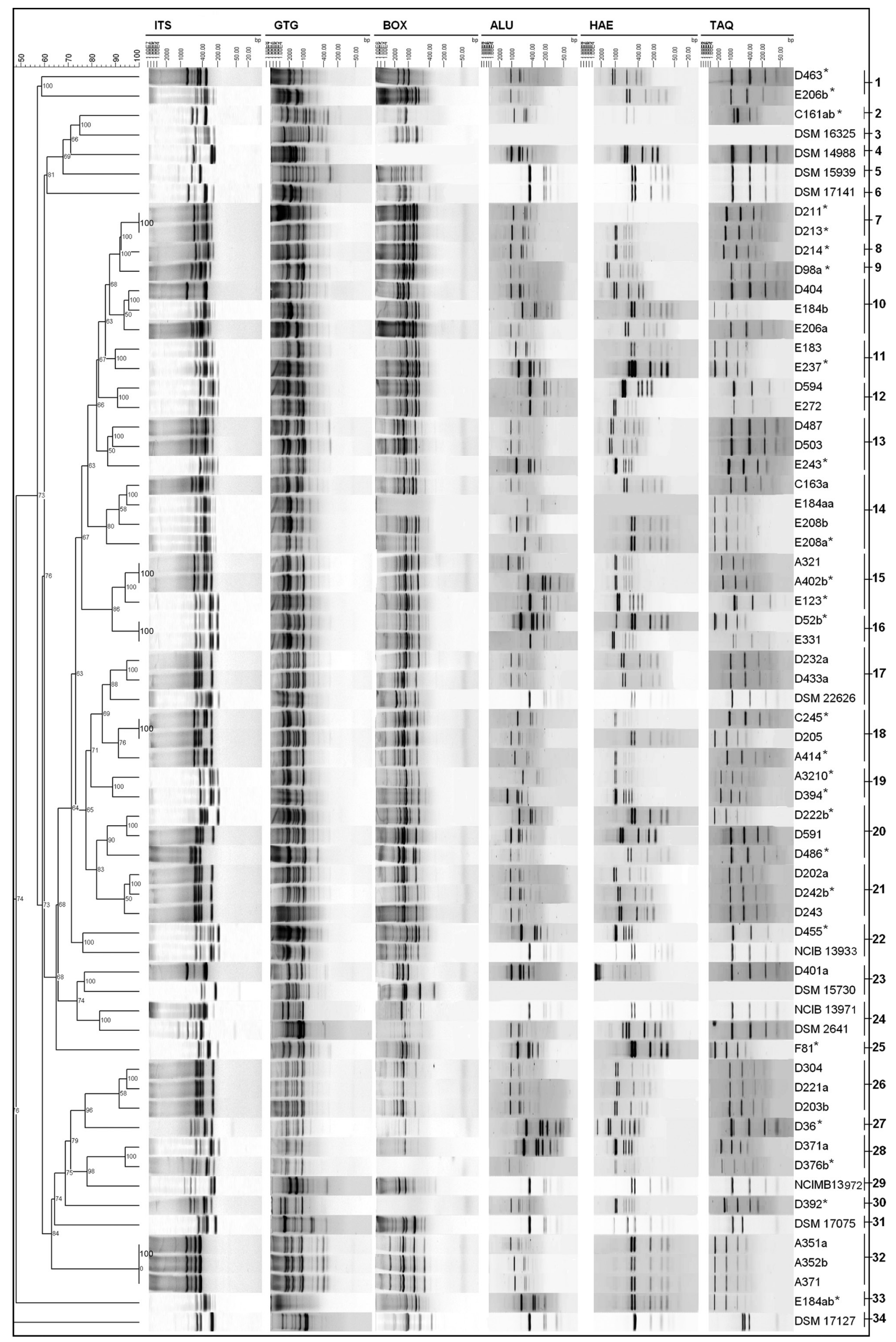


Table IV

Contents of the clusters of Anoxybacillus isolates and reference strains derived from individual ARDRA profiles and ITS-, BOXand GTG-PCR fingerprintings

\begin{tabular}{|c|c|c|c|c|c|c|}
\hline & \multicolumn{3}{|c|}{ ARDRA profiles of $16 \mathrm{~S}$ rRNA gene } & \multirow{2}{*}{ ITS-PCR profiles } & \multicolumn{2}{|c|}{ Rep-PCR profiles } \\
\hline & AluI & HaeIII & TaqI & & BOC-PCR & GTG-PCR \\
\hline 1 & $\mathrm{~A} 3210=\mathrm{D} 371 \mathrm{a}$ & E206a $\approx 2641$ & $\mathrm{~A} 3210 \approx \mathrm{D} 455$ & $\begin{array}{c}\mathrm{A} 351 \mathrm{a}=\mathrm{A} 371 \\
=\mathrm{A} 352 \mathrm{~b}\end{array}$ & $\mathrm{~A} 321=\mathrm{E} 272$ & $\mathrm{E} 206 \mathrm{~b}^{*}$ \\
\hline 2 & E208a* $^{*}$ & $\mathrm{E} 206 \mathrm{~b}^{*}$ & $\mathrm{D}^{2} 76 \mathrm{~b}^{*}$ & $\mathrm{D}_{463^{*}}$ & $\begin{array}{c}\mathrm{D} 52 \mathrm{~b}=\mathrm{E} 184 \mathrm{~b} \\
=\mathrm{E} 208 \mathrm{~b}\end{array}$ & $15939^{\star}$ \\
\hline 3 & $\mathrm{D} 455 \approx \mathrm{E} 184 \mathrm{~b}$ & $\mathrm{D} 232 \mathrm{a} \approx \mathrm{D} 433 \mathrm{a}$ & $\mathrm{E} 272 \approx \mathrm{E} 331$ & $13972^{\star}$ & $\begin{array}{c}\mathrm{A} 3210=\mathrm{A} 402 \mathrm{~b} \\
\approx \mathrm{F} 81\end{array}$ & $13971^{\star}$ \\
\hline 4 & E184ab* & $13972^{\star}$ & D594 = E123 & D486* & $\mathrm{E} 123=\mathrm{E} 331$ & $2641^{\star}$ \\
\hline 5 & $\mathrm{D}_{52} \mathrm{~b}^{*}$ & $\mathrm{C} 163 \mathrm{a} \approx \mathrm{D} 594$ & $\mathrm{~A} 402 \mathrm{~b}=\mathrm{D} 214$ & $2641^{\star}$ & D594 = E237 & $17075^{\star}$ \\
\hline 6 & $\begin{array}{c}15939=17141 \\
=22626=13933 \\
=13972\end{array}$ & $22626^{*}$ & $\mathrm{C}_{161 \mathrm{ab}^{*}}$ & $15939^{*}$ & E243* & $\mathrm{D}^{2} 01 \mathrm{a}^{*}$ \\
\hline 7 & 13971 & E123* & $17127^{\star}$ & $\mathrm{C}_{161 \mathrm{ab}}^{*}$ & $22626^{\star}$ & $16325^{\star}$ \\
\hline 8 & 17127 & D304 = D221a & $15939=17141$ & $17075^{\star}$ & $\mathrm{D} 222 \mathrm{~b}=\mathrm{D} 394$ & $\mathrm{C}_{161 \mathrm{ab}}^{*}$ \\
\hline 9 & $\mathrm{C} 161 \mathrm{ab}=\mathbf{1 7 0 7 5}$ & $\mathrm{D} 242 \mathrm{~b}=\mathrm{D} 243$ & $17075^{\star}$ & $16325^{\star}$ & $17141^{\star}$ & $13972^{\star}$ \\
\hline 10 & $\begin{array}{c}\mathrm{D} 594=\mathrm{E} 123 \\
=\mathrm{E} 272=\mathrm{E} 331\end{array}$ & $\mathrm{D} 591 \approx \mathbf{1 3 9 7 1}$ & $\begin{array}{c}\mathrm{D} 498 \mathrm{a}=\mathrm{D} 487 \\
=\mathrm{D} 503\end{array}$ & $\begin{array}{c}\mathrm{E} 184 \mathrm{ab}=\mathrm{E} 208 \mathrm{~b} \\
=\mathrm{E} 184 \mathrm{aa}=\mathrm{E} 184 \mathrm{~b} \\
=\mathrm{E} 208 \mathrm{a}\end{array}$ & $\begin{array}{l}\mathrm{E} 183=\mathrm{E} 206 \mathrm{~b} \\
\quad=\mathrm{E} 184 \mathrm{ab}\end{array}$ & $14988^{\star}$ \\
\hline 11 & $\mathrm{~A} 402 \mathrm{~b}^{*}$ & $\mathrm{D} 404 \approx \mathrm{D} 463$ & $22626=\mathrm{D} 404$ & $\mathrm{E} 183=\mathrm{E} 206 \mathrm{~b}$ & $\mathrm{D} 455=\mathrm{E} 184 \mathrm{aa}$ & $\begin{array}{l}\mathrm{D} 211=\mathrm{D} 213 \\
=\mathrm{D} 214 \mathrm{D} 98 \mathrm{a}\end{array}$ \\
\hline 12 & $\mathrm{~A} 352 \mathrm{~b}=\mathrm{A} 371$ & $\mathrm{D} 202 \mathrm{a}=\mathrm{D} 203 \mathrm{~b}$ & $\begin{array}{c}\mathrm{D} 401 \mathrm{a}=\mathrm{D} 463 \\
=\mathbf{1 3 9 7 2}=\mathbf{1 3 9 7 1}\end{array}$ & $\mathrm{A} 3210=\mathrm{D} 594$ & $\mathrm{D} 371 \mathrm{a}=\mathrm{D} 36$ & $\mathrm{D} 404 \approx \mathrm{E} 184 \mathrm{~b}$ \\
\hline 13 & $\mathrm{~A} 414^{*}$ & $15939^{\star}$ & $\mathrm{D} 36^{*}$ & $\mathrm{E} 243=\mathrm{E} 272$ & E208a ${ }^{*}$ & E206a ${ }^{*}$ \\
\hline 14 & $\mathrm{E} 183=\mathrm{E} 208 \mathrm{~b}$ & $\mathrm{E} 272=\mathrm{E} 331$ & $\begin{array}{c}2641=14988 \\
=13933\end{array}$ & D214* & $\mathrm{D} 376 \mathrm{~b}=\mathbf{1 3 9 3 3}$ & $\mathrm{E} 183=\mathrm{E} 237$ \\
\hline 15 & $\mathrm{D} 214 \approx 14988$ & $\begin{array}{c}\mathrm{A} 414=\mathrm{D} 371 \mathrm{a} \\
=\mathrm{D} 376 \mathrm{~b}=\mathrm{D} 455 \\
=\mathrm{E} 243=\mathrm{D} 392 \\
=\mathrm{D} 394\end{array}$ & $\mathrm{D} 304=\mathrm{D} 221 \mathrm{a}$ & $\mathrm{D} 455^{*}$ & $\mathrm{D} 232 \mathrm{a}=\mathrm{D} 242 \mathrm{~b}$ & $\mathrm{D} 594=\mathrm{E} 272$ \\
\hline 16 & $\begin{aligned} & \mathrm{D} 304=\mathrm{D} 205 \\
= & \mathrm{D} 232 \mathrm{a}=\mathrm{D} 392 \\
= & \mathrm{D} 487=\mathrm{A} 351 \mathrm{a}\end{aligned}$ & $\begin{array}{c}\mathrm{A} 321=\mathrm{A} 3210 \\
=\mathrm{A} 402 \mathrm{~b}=\mathrm{C} 245 \\
=\mathrm{D} 211=\mathrm{D} 213 \\
=\mathrm{D} 214\end{array}$ & $\mathrm{D} 202 \mathrm{a}=\mathrm{D} 203 \mathrm{~b}$ & $\mathrm{E} 237^{\star}$ & $\mathrm{D} 211^{\star}$ & $\begin{array}{l}\mathrm{D} 487=\mathrm{D} 503 \\
\quad=\mathrm{E} 243\end{array}$ \\
\hline 17 & $\begin{array}{c}C 163 \mathrm{a}=\mathrm{D} 243 \\
=\mathrm{D} 433 \mathrm{a}=\mathrm{D} 486 \\
=\mathrm{D} 503=\mathrm{E} 206 \mathrm{a} \\
=\mathrm{E} 206 \mathrm{~b}=\mathbf{2 6 4 1} \\
=\mathrm{D} 591\end{array}$ & D98a* & $\mathrm{A} 414^{*}$ & $\mathrm{E} 123=\mathrm{E} 331$ & D591* & $\begin{array}{c}\mathrm{C} 163 \mathrm{a}=\mathrm{E} 184 \mathrm{aa} \\
=\mathrm{E} 208 \mathrm{~b}\end{array}$ \\
\hline 18 & $\begin{array}{c}\mathrm{D} 401 \mathrm{a}=\mathrm{D} 463 \\
=\mathrm{D} 404=\mathrm{D} 98 \mathrm{a} \\
=\mathrm{D} 202 \mathrm{a}\end{array}$ & $14988^{\star}$ & D211* & $\begin{array}{c}\mathrm{D} 371 \mathrm{a}=\mathrm{D} 52 \mathrm{~b} \\
\quad \approx 13933\end{array}$ & $\mathrm{C} 163 \mathrm{a}=\mathrm{D} 213$ & E208a* \\
\hline 19 & $\begin{array}{c}\mathrm{D} 221 \mathrm{a}=\mathrm{D} 242 \mathrm{~b} \\
=\mathrm{D} 203 \mathrm{~b}\end{array}$ & $\mathrm{D} 487 \approx \mathrm{D} 503$ & A $3210^{*}$ & D394* & D503* & $\begin{array}{c}\mathrm{A} 321=\mathrm{A} 402 \mathrm{~b} \\
=\mathrm{E} 123\end{array}$ \\
\hline 20 & $\mathrm{~A} 321 \approx \mathrm{D} 394$ & $\mathrm{D} 36^{*}$ & D243 = D591 & $22626^{\star}$ & $\mathrm{C} 245^{*}$ & $\mathrm{D} 52 \mathrm{~b}=\mathrm{E} 331$ \\
\hline 21 & D376b* & $\begin{array}{c}\mathrm{A} 352 \mathrm{~b}=\mathrm{D} 205 \\
=\mathrm{A} 371=\mathrm{A} 351 \mathrm{a} \\
=\mathrm{E} 183=\mathrm{D} 401 \mathrm{a} \\
\approx \mathbf{1 7 1 4 1}\end{array}$ & D242b* & $\mathrm{D} 222 \mathrm{~b}^{\star}$ & $\begin{array}{c}\mathrm{D} 98 \mathrm{a}=\mathrm{D} 214 \\
=\mathrm{E} 06 \mathrm{a}\end{array}$ & D455* \\
\hline 22 & $\mathrm{E} 237 \approx \mathrm{E} 243$ & $\begin{array}{c}\mathrm{E} 184 \mathrm{ab}=\mathrm{E} 208 \mathrm{a} \\
=\mathrm{E} 208 \mathrm{~b}=\mathrm{F} 81 \\
=\mathrm{E} 184 \mathrm{aa}=\mathrm{E} 184 \mathrm{~b} \\
=\mathrm{E} 237=\mathrm{D} 222 \mathrm{~b} \\
=\mathrm{D} 52 \mathrm{~b}\end{array}$ & E243* & $\mathrm{F} 81^{*}$ & $\begin{array}{c}\mathrm{D} 202 \mathrm{a}=\mathrm{D} 205 \\
=\mathrm{D} 433 \mathrm{a}\end{array}$ & $\mathrm{A} 3210=\mathrm{D} 394$ \\
\hline
\end{tabular}


Table IV continued

\begin{tabular}{|c|c|c|c|c|c|c|}
\hline & \multicolumn{3}{|c|}{ ARDRA profiles of $16 \mathrm{~S}$ rRNA gene } & \multirow{2}{*}{ ITS-PCR profiles } & \multicolumn{2}{|c|}{ Rep-PCR profiles } \\
\hline & AluI & HaeIII & TaqI & & BOC-PCR & GTG-PCR \\
\hline 23 & $\mathrm{D}^{2} 2 \mathrm{~b}^{*}$ & $13933 \approx 17127$ & $\begin{array}{c}\text { D486 = E206b } \\
=E 206 a\end{array}$ & $\mathrm{D} 487=\mathrm{D} 503$ & $\mathrm{~A} 414^{*}$ & $\mathrm{C} 245 \approx \mathrm{D} 205$ \\
\hline 24 & $\mathrm{C} 245 \approx \mathrm{F} 81$ & $\mathrm{C} 161 \mathrm{ab}=\mathbf{1 7 0 7 5}$ & $\mathrm{D} 371 \mathrm{a}=\mathrm{D} 394$ & D376b* & D243* & $\mathrm{A} 414^{*}$ \\
\hline 25 & $\mathrm{D} 211 \approx \mathrm{D} 213$ & $\mathrm{D} 486^{*}$ & $\begin{array}{c}\mathrm{C} 163 \mathrm{a}=\mathrm{D} 433 \mathrm{a} \\
=\mathrm{D} 232 \mathrm{a}\end{array}$ & $\mathrm{C} 163 \mathrm{a} \approx 13971$ & $\mathrm{D} 487^{\star}$ & $\mathrm{D} 222 \mathrm{~b}=\mathrm{D} 591$ \\
\hline 26 & $\mathrm{E} 184 \mathrm{aa} \approx \mathrm{D} 36$ & $15730^{\star}$ & $\mathrm{C} 245^{\star}$ & $\mathrm{D} 98 \mathrm{a} \approx \mathrm{E} 206 \mathrm{a}$ & $13972^{\star}$ & D486* \\
\hline 27 & $15730^{*}$ & $16325^{\star}$ & $\begin{array}{c}\mathrm{E} 184 \mathrm{ab}=\mathrm{E} 184 \mathrm{~b} \\
=\mathrm{A} 371=\mathrm{D} 205 \\
=\mathrm{D} 222 \mathrm{~b}=\mathrm{E} 183 \\
=\mathrm{E} 184 \mathrm{a} a=\mathrm{E} 208 \mathrm{a} \\
=\mathrm{D} 52 \mathrm{~b}=\mathrm{E} 208 \mathrm{~b} \\
=\mathrm{F} 81=\mathrm{E} 237 \\
=\mathrm{A} 351 \mathrm{a}=\mathrm{A} 352 \mathrm{~b}\end{array}$ & $\mathrm{D} 401 \mathrm{a}=\mathrm{D} 404$ & $16325^{\star}$ & $\begin{array}{c}\mathrm{D} 202 \mathrm{a}=\mathrm{D} 242 \mathrm{~b} \\
=\mathrm{D} 243\end{array}$ \\
\hline 28 & $16325^{*}$ & - & D392* & $17141^{*}$ & $\mathrm{D} 221 \mathrm{a} \approx \mathbf{1 3 9 7 1}$ & $22626^{*}$ \\
\hline 29 & - & - & $\mathrm{D} 213^{*}$ & $\begin{array}{c}\mathrm{A} 414=\mathrm{C} 245 \\
=\mathrm{A} 402 \mathrm{~b}\end{array}$ & $\mathrm{D} 203 \mathrm{~b}=\mathrm{D} 304$ & $13933^{\star}$ \\
\hline 30 & - & - & $15730^{*}$ & D392= D36 & $15939^{*}$ & F81* \\
\hline 31 & - & - & $16325^{\star}$ & $\begin{array}{c}\mathrm{D} 211=\mathrm{D} 213 \\
=\mathrm{A} 321\end{array}$ & $17127^{\star}$ & $\begin{array}{c}\mathrm{D} 232 \mathrm{a}=\mathrm{D} 433 \mathrm{a} \\
=\mathrm{D} 203 \mathrm{~b}\end{array}$ \\
\hline 32 & - & - & - & $14988^{*}$ & D486* & $\mathrm{D} 371 \mathrm{a}=\mathrm{D} 376 \mathrm{~b}$ \\
\hline 33 & - & - & - & $17127^{\star}$ & $2641^{*}$ & $\begin{array}{c}\mathrm{D} 36=\mathrm{D} 304 \\
=\mathrm{D} 221 \mathrm{a}\end{array}$ \\
\hline 34 & - & - & - & $\begin{aligned} & \mathrm{D} 205=\mathrm{D} 242 \mathrm{~b} \\
= & \mathrm{D} 232 \mathrm{a}=\mathrm{D} 202 \mathrm{a} \\
= & \mathrm{D} 203 \mathrm{~b}=\mathrm{D} 304 \\
= & \mathrm{D} 221 \mathrm{a}=\mathrm{D} 243 \\
= & \mathrm{D} 433 \mathrm{a}=\mathrm{D} 591\end{aligned}$ & $\begin{array}{c}\mathrm{A} 352 \mathrm{~b}=\mathrm{A} 371 \\
=\mathrm{A} 351 \mathrm{a}\end{array}$ & D392* \\
\hline 35 & - & - & - & $15730^{*}$ & $17075^{\star}$ & $17141^{\star}$ \\
\hline 36 & - & - & - & - & $\mathrm{D} 401 \mathrm{a}=\mathrm{D} 404$ & D463* \\
\hline 37 & - & - & - & - & C161ab* & $\begin{array}{c}\mathrm{A} 351 \mathrm{a}=\mathrm{A} 352 \mathrm{~b} \\
=\mathrm{A} 371\end{array}$ \\
\hline 38 & - & - & - & - & $14988^{\star}$ & E184ab* \\
\hline 39 & - & - & - & - & D463* & $17127^{\star}$ \\
\hline 40 & - & - & - & - & D392* & $15730^{*}$ \\
\hline 41 & - & - & - & - & $15730^{*}$ & - \\
\hline
\end{tabular}

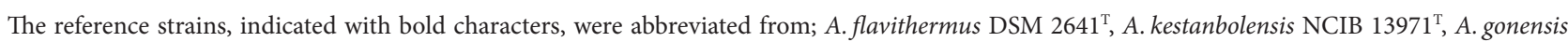
NCIB 13933 ${ }^{\mathrm{T}}$, A. ayderensis NCIB 13972 $2^{\mathrm{T}}$, A. thermarum DSM 17141 ${ }^{\mathrm{T}}$, A. kamchatkensis DSM 14988 ${ }^{\mathrm{T}}$, A. amylolyticus DSM 15939 , A. rupiensis DSM $17127^{\mathrm{T}}$, A. voinovskiensis DSM $17075^{\mathrm{T}}$, A. tepidamans DSM $16325^{\mathrm{T}}$, A. thermarum DSM $17141^{\mathrm{T}}$, A. salavatliensis DSM $22626^{\mathrm{T}}$. The bacteria having: “ $\approx$ "; the similar (displaying similarities between $75.0-99.9 \%)$, “=”; the same (100\% similarity), "*”; the unique and distinctive (similarities between $0-16.7 \%$ ) profiles on the fingerprinting tests used.

ITS-PCR products of the 53 Anoxybacillus isolates and 12 type strains generated totally 35 clusters. As in the case of Rep-PCR analyses, while the ITS banding patterns of all the type strains showed distinctive profiles from each other and from all the isolates, 10 of the isolates displayed unique fingerprintings from all the others. In addition, none of the isolates shared banding patterns with the reference strains.

In conclusion, it is obvious that the ITS-PCR, (GTG) $)_{5}$ PCR and BOX-PCR products generated a high number of bands giving discriminative infor- mation below species and subspecies level between these Anoxybacillus isolates and strains studied, when compared with the ARDRA analyses of their 16S rRNA genes. Therefore, as the higher numbers of banding patterns were obtained, and as none of the isolates showed the same profile with the references, the cluster analyses of the Rep- and ITS-PCR fingerprintings allowed us to differentiate these isolates and reference strains genetically from each other, and also to group them the in higher numbers according to their distinctive fingerprints. 


\section{Discussion}

The 16S rRNA gene is known to be a good molecular clock as its primary structure is highly conserved, and thus 16S rRNA gene sequencing is one of the widely used standard techniques in modern bacterial taxonomy by forming the basis of the bacterial phylogeny (Rosello-Mora, 2005). It is also routinely used to apply the rRNA gene technology as a part of 'polyphasic approach' when new descriptions of bacterial species or higher taxa are made (Ludwig and Schleifer, 1999). There are some limitations when comparing the $16 \mathrm{~S}$ rRNA gene sequences of phylogenetically homogeneous groups of bacteria as in the case of the genus Anoxybacillus. One of the limitation factors is that the structurally conserved sequences found in $16 \mathrm{~S}$ rRNA gene might not allow strains to be identified up to species level in closely related microorganisms (Rodas et al., 2003). On the other hand, the Ad Hoc Committee strongly recommended the DNA-DNA hybridizations in cases of species descriptions, when 16S rRNA gene sequences of the novel species show $97.0 \%$ or more similarity with its closest relatives (Stackebrandt and Goebel 1994; Stackebrandt et al., 2002; Logan et al., 2009).

The $16 \mathrm{~S}$ rRNA gene sequence analyses carried out in this study revealed that genus Anoxybacillus with its 53 isolates was the most dominant genus having carbohydrate degrading activities in the examined geothermal regions of Turkey. Nearly all of the Anoxybacillus isolates were also found to be able to produce carbohydrate degrading enzymes such as amylase and glucosidase. This could be explained by the often occurrence of starch not only in nature and but also in these extreme hot environments and its easy degradation (Derekova et al., 2008). In addition, the presence of biotechnologically important enzyme producing Anoxybacillus isolates was also determined for further researches.

Comparison of the generated 16S rRNA gene sequences with all the other described Anoxybacillus type strains in the GenBank database indicated that the thermophilic Anoxybacillus isolates were mainly diverged into eight phylogenetic groups. The majority of the identified isolates from geothermal areas of Turkey showed the most similarity to their closest relatives; A. salavatliensis and A. kamchatchensis subsp. asaccharedens type strains. Furthermore, based on these phylogenetic analyses, it was determined that all the identified fifty one Anoxybacillus isolates were found to be related within the phylogenetically homogenous Anoxybacillus type strains of A. flavithermus, A. flavithermus subsp. flavithermus, A. salavatliensis, A. thermarum, A. kamchatkensis and A. kamchatkensis subsp. asaccharedens which shared 16S rRNA gene sequence similarity values from $97.4 \%$ to $99.9 \%$. As this homogenous group of Anoxybacillus type strains, demonstrated a significant amount of high intragenic sequence similarity, all of them were closely related species and could only be differentiated from each other by DNA-DNA hybridization analysis, according to the recommendations of the Ad Hoc Committee.

On behalf of these explanations, the identified 51 Anoxybacillus isolates, related with these Anoxybacillus type strains, showed more than $97.0 \%$ sequence similarity (except A321, and C161ab) to more than one closest relatives. Thus, it seems to be that most of the isolates require to be hybridized with their closest relatives as in the case of the reference strains, and it can also be concluded that $16 \mathrm{~S}$ rRNA sequencing is not generally an informative and conclusive way for the identification of species from this genetically homogeneous members belonging to genus Anoxybacillus.

Moreover, isolate A321, which was branched in Cluster 1 with the other isolates resembling A. salavatliensis, could not be identified as an A. salavatliensis species as it had a sequence similarity value lower than $96.0 \%$ to this strain and to all the other described Anoxybacillus type strains. As in the case of A321 isolate, C161ab which was the unique member of the Cluster 7 also proposed to be a novel species due to its low level $16 \mathrm{~S}$ rRNA gene sequence similarities $(<97.0 \%)$ among all the validly published Anoxybacillus type strains. Therefore, this study introduced two potentially novel Anoxybacillus species and the sequence comparisons and fingerprinting patterns of these two isolates were promising their novelty among genus Anoxybacillus and lead to their further genotypic and phenotypic analysis.

In addition, ARDRA profiles have been well-studied among the thermophilic, spore-forming bacteria, but there is no report demonstrating the ARDRA patterns for the species of the genus Anoxybacillus (Caccamo et al., 2001; Kuisiene et al., 2002). Therefore, the restriction patterns of the amplified PCR products digested with AluI, HaeIII and TaqI restriction enzymes of the Anoxybacillus isolates and reference strains were taken into cluster analyses. In total 28, 27 and 31 experimental ARDRA profiles were observed, based on the individual AluI, HaeIII and TaqI digestions, respectively. Among these patterns, the TaqI restriction sites were higher than the other two restriction enzymes, thus the TaqI restriction fragments were thought to be generally more differentiative for genus Anoxybacillus with its 31 clusters, whereas only the clusters obtained from HaeIII-ARDRA analysis were able to differentiate the 12 reference strains to 11 unique clusters. Nevertheless, since the ARDRA analyses were carried out from conserved 16S rRNA gene, the results were not so satisfactory to identify the Anoxybacillus isolates and this factor mostly limited distinguishing the Anoxybacillus isolates and reference strains up to species level from each other. 
The Repetitive Extragenic Palindromic (Rep) elements such as BOX and (GTG) ${ }_{5}$ are known as evolutionary conserved sequences in prokaryotic genomes and can be used as oligonucleotide binding sites for PCR-mediated genomic fingerprinting (Rep-PCR). The Rep-PCR can be used to discriminate strains at the species and subspecies level (Versalovic et al., 1994). RepPCR has been used in a few studies for the determination of the genetic diversity among the Anoxybacillus species (De Clerck et al., 2004; Adiguzel et al., 2009; Cihan et al., 2011; Inan et al., 2011). All these studies concluded that the rep-PCR fingerprinting technique was a rapid, easy-to-perform, and reproducible tool for differentiation of thermophilic bacteria at the species and subspecies level. Beside these fingerprinting methods, the intergenic transcribed spacers (ITS) between the $16 \mathrm{~S}$ and the $23 \mathrm{~S}$ rRNA genetic loci are frequently used in PCR fingerprinting to discriminate at the species and intraspecies levels. The polymorhism in the ITS is due to the presence of tRNA genes that contain multiple ribosomal operons which differ in length and sequence (Daffonchio et al., 2003). This polymorphism was only used for discriminating A. gonensis and A. salavatliensis from their closely related Anoxybacillus species in previous studies of Belduz et al. (2003) and Cihan et al. (2011).

In the individual cluster analyses of all the Anoxybacillus isolates and type strains derived from the (GTG) ${ }_{5}$ and BOX-PCR, and ITS-PCR fingerprintings, totally 41,40 , and 35 clusters were formed. Furthermore, all these three tests allowed us to differentiate the 12 Anoxybacillus reference strains not only from each other, but also from all the isolates. As these tests were determined on non-conservative 16S-23S rRNA gene sequences like ITS region, or on repetitive genetic elements throughout the whole genome such as (GTG) and BOX elements, the results were more informative about the genetic diversity of the isolates and reference strains. None of the isolates represented the same banding patterns with the reference strains in the Repand ITS-PCR analyses, which were formerly found as sharing high $16 \mathrm{~S}$ rRNA gene sequence similarities and therefore they may not be assigned to their closely related species according to these results.

In conclusion, when these six fingerprintings were combined in a cumulative cluster analysis, a total of 34 clusters was obtained (Fig. 2). In addition, 35 of 53 isolates showed unique patterns different from all the other isolates and reference strains at least from two of these six fingerprinting analyses used. The ITSPCR, (GTG) ${ }_{5}$-PCR and BOX-PCR products generated a high number of bands giving discriminative information below species and subspecies level between these Anoxybacillus isolates and references, when compared with the ARDRA analyses. The Rep- and ITS-PCR fin- gerprinting patterns allowed us to differentiate these isolates and reference strains genetically, and also to group them in higher numbers according to their distinctive fingerprints. Therefore, we could certainly conclude that most of our isolates genetically diverged from the reference strains at least from the species or subspecies level.

This research also revealed that the ability of carbohydrate degradation effects the high population of genus Anoxybacillus in these geothermal regions and make them superior among the other thermophilic endospore-forming bacilli in these habitats. In this study, not only the phylogenetic diversity of a large collection of isolates belonging to genus Anoxybacillus were analyzed, but also the efficiency of $16 \mathrm{~S}$ rRNA gene sequencing, ARDRA techniques, rep-PCR and also ITS-PCR fingerprintings were discussed. According to this survey, the genus Anoxybacillus was found to be genetically a very homogenous group of bacteria as both isolates and type strains showed high levels of intragenic sequence $16 \mathrm{~S}$ rRNA gene similarities and isolates having more than $97 \%$ sequence similarities need to be DNADNA hybridization analysis with their closest relatives. Thus, most of the isolates will have to be hybridized with more than one relative. Nevertheless, when these easy, having low-cost and single-performance fingerprinting techniques of Rep- and ITS-PCR were applied before carrying out high-cost and labour-requiring hybridization tests with all the closest relatives, they would be very helpful to decide which relatives need to be hybridized according to the differences in their fingerprinting patterns. This will also aid to decrease the number of hybridization analyses with some of these relatives, which will give low similarities than expected, as revealed before in the first identification and description of type strain A. salavatliensis (Cihan et al., 2011).

Although there were studies with these fingerprinting techniques, this is the first, which a large number of Anoxybacillus isolates and reference strains were used by a polyphasic approach and which the success of these tests were demonstrated on characterization and differentiating Anoxybacillus isolates. All these results concluded that especially when Rep-PCR and ITS-PCR fingerprinting techniques were combined with other 16S rRNA gene sequence based analyses, they would consider as easy and accurate genotypic tools before deciding the hybridization pairs for the identification purposes.

\section{Acknowledgements}

This research was supported by Fundamental Research Group of The Scientific and Technological Research Council of Turkey (TUBITAK); project number TBAG/HD-320 (107T286). In addition we are very grateful to Prof. Dr. Hakan Akbulut (Ankara University, Faculty of Medicine, Oncology Department, Ankara, Turkey) and Associated Prof. Dr. Hilal Ozdag (Ankara University, Biotechnology Institute Central Laboratory, Genomic Unite, Ankara, Turkey) for their contributions. 


\section{Literature}

Atanassova M., A. Derekova, R. Mandeva, C. Sjøholm and M. Kambourova. 2008. Anoxybacillus bogrovensis sp. nov., a novel thermophilic bacterium isolated from a hot spring in Dolni Bogrov, Bulgaria. Int. J. Syst. Evol. Microbiol. 58: 2359-2362.

Adiguzel A, H. Ozkan, O. Baris, K. Inan, M. Gulluce and F. Sahin. 2009 Identification and characterization of thermophilic bacteria isolated from hot spring in Turkey. J. Microbiol. Methods. 79: $321-328$

Belduz A.O., S. Dulger and Z. Demirbag. 2003. Anoxybacillus gonensis sp. nov., a moderately thermophilic, xylose-utilizing, endospore-forming bacterium. Int. J. Syst. Evol. Microbiol. 53: 1315-1320. Caccamo D., T.L. Maugeri and C. Guglisndolo. 2001. Identification of thermohilic and marine bacilli from shallow thermal vents by restriction analysis of their amplified 16S rRNA. J. Appl. Microbiol. 91: 520-524.

Cihan A.C., C. Cokmus and B. Ozcan. 2009. Characterization of thermostable a-glucosidases from newly isolated Geobacillus sp. A333 and thermophilic bacterium A343. World J. Microbiol. Biotechnol. 25: 2205-2217.

Cihan A.C., B. Ozcan and C. Cokmus 2011. Anoxybacillus salavatliensis sp. nov., an $\alpha$-glucosidase producing, thermophilic bacterium isolated from Salavatli, Turkey. J. Basic Microbiol. 51: 136-146.

Claus D. and C.W. Berkeley. 1986. The genus Bacillus In: Bergey's Manual of Systematic Bacteriology. Volume 2. Sneath pHA (Ed.) Williams, Wilkins, Baltimore, ISBN: 0-683-07893-934, pp. 1105-1139. Colak A., D. Sisik, N. Saglam, S. Güner, S. Canakci and A.O. Belduz. 2005. Characterization of a thermoalkalophilic esterase from a novel thermophilic bacterium, Anoxybacillus gonensis G2. Bioresour. Technol. Mar. 96: 625-631.

Coleri A., C. Cokmus, B. Ozcan, N. Akkoc and M. Akcelik. 2009. Isolations of a-glucosidase-producing thermophilic bacilli from hot springs of Turkey. Microbiol. 78: 56-66.

Coorevits A., A.E., Dinsdale, G. Halket, L. Lebbe, P. De-Vos, A. Van-Landschoot and N.A. Logan. 2012. Taxonomic revision of the genus Geobacillus: emendation of Geobacillus, G. stearothermophilus, G. jurassicus, G. toebii, G. thermodenitrificans and G. thermoglucosidans (nom. corrig., formerly 'thermoglucosidasius'); transfer of Bacillus thermantarcticus to the genus as G. thermantarcticus comb. nov.; proposal of Caldibacillus debilis gen. nov., comb. nov.; transfer of G. tepidamans to Anoxybacillus as A. tepidamans comb. nov.; and proposal of Anoxybacillus caldiproteolyticus sp. nov. Int. J. Syst. Evol. Microbiol. 62: 1470-1485.

Daffonchio D., A. Cherif, L. Brusetti, A. Rizzi, D. Mora, A. Boudabous and S. Borin. 2003. Nature of polymorphisms in 16S-23S rRNA gene intergenic transcribed spacer fingerprinting of Bacillus and related genera. Appl. Environ. Microbiol. 69: 5128-5137.

Dai J., Y. Liu, Y. Lei, Y. Gao, F. Han, Y. Xiao and H. Peng. 2011. A new subspecies of Anoxybacillus flavithermus ssp. yunnanensis ssp. nov. with very high ethanol tolerance. FEMS Microbiol. Lett. 320: 72-78.

De Clerck E., M. Rodríguez-Díaz, T. Vanhoutte, J. Heyrman, N.A. Logan and P. De Vos. 2004. Anoxybacillus contaminans sp. nov. and Bacillus gelatini sp. nov., isolated from contaminated gelatin batches. Int. J. Syst. Evol. Microbiol. 54: 941-946.

Demirjian D.C., F. Moris-Varas and C.S. Cassidy. 2001. Enzymes from extremophiles. Curr. Oppinion Chem. Biol. 5: 144-151.

Derekova A., C. Sjøholm, R. Mandeva and M. Kambourova. 2007. Anoxybacillus rupiensis sp. nov., a novel thermophilic bacterium isolated from Rupi basin (Bulgaria). Extremophiles 11: 577-583.

Derekova A., R. Mandeva and M. Kambourova. 2008. Phylogenetic diversity of thermophilic carbohydrate degrading bacilli from Bulgarian hot springs. World J. Microbiol. Biotechnol. 24: 1697-1702.
Dulger S., Z. Demirbag and A.O. Belduz. 2004. Anoxybacillus ayderensis sp. nov. and Anoxybacillus kestanbolensis sp. nov. Int. J. Syst. Evol. Microbiol. 54: 1499-1503.

Ertunga N.S., A. Colak, A.O. Belduz, S. Canakci, H. Karaoglu and C. Sandalli. 2007. Cloning, Expression, Purification and characterization of Fructose-1,6-bisphosphate Aldolase from Anoxybacillus gonensis G2. J. Biochem. 141: 817-825.

Gul-Guven R., K. Guven, A. Poli and B.J. Nicolaus. 2008. Anoxybacillus kamchatkensis subsp. asaccharedens subsp. nov., a thermophilic bacterium isolated from a hot spring in Batman. J. Gen. Appl. Microbiol. 54: 327-334.

Inan K., A.O. Belduz and S. Canakci. 2012. Anoxybacillus kaynarcensis sp. nov., a moderately thermophilic, xylanase producing bacterium. J. Basic Microbiol. doi: 10.1002/jobm.201100638.

Jukes T.H. and C.R. Cantor. 1969. Evolution of protein molecules. In: Munro HN (ed) Mammalian Protein Metabolism, Academic Press, New York, pp. 21-132.

Kacagan M., S. Canakci, C. Sandalli, K. Inan, D.N. Colak and A.O. Belduz. 2008. Characterization of a xylanase from a thermophilic strain of Anoxybacillus pushchinoensis A8. Biologia 63: 599-606.

Kevbrin V.V., K. Zengler, A.M. Lysenko and J. Wiegel. 2005. Anoxybacillus kamchatkensis sp. nov., a novel thermophilic facultative aerobic bacterium with a broad $\mathrm{pH}$ optimum from the Geyser valley, Kamchatka. Extremophiles 9: 391-398

Kim O.S., Y.J. Cho, K. Lee, S.H. Yoon, M. Kim, H. Na, S.C. Park, Y.S. Jeon, J.H. Lee, H. Yi, S. Won and J. Chun. 2012. Introducing EzTaxon-e: a prokaryotic $16 \mathrm{~S}$ rRNA Gene sequence database with phylotypes that represent uncultured species. Int. J. Syst. Evol. Microbiol. 62: 716-721.

Kuisiene N., R. Jomantiene, D. Valiunas and D. Chitavichius. 2002. Characterization of thermophilic proteolytic spore-forming bacteria from a geothermal site in Lithuania based on 16S rRNA RFLP and ITS-PCR analyses. Microbiol. 71: 712-716.

Lavrenteva E.V., A.P. Shagzhina, O.B. Babasanova, Y.E. Dunaevsky, Z.B. Namsaraev and D.D. Barkhutova. 2009. The study of two alkaliphilic thermophile bacteria of the Anoxybacillus genus as producers of extracellular proteinase. Appl. Biochem. Micro. 45: 484-488.

Logan N.A. O. Berge, A.H. Bishop, H.J. Busse, P. De Vos, D. Fritze, M. Heyndrickx, P. Kämpfer, L. Rabinovitch, M.S. SalkinojaSalonen and others. 2009. Proposed minimal standards for describing new taxa of aerobic, endospore-forming bacteria. Int. J. Syst. Evol. Microbiol. 59: 2114-2121.

Ludwig W and K.H. Schleifer. 1999. Phylogeny of Bacteria beyond the 16S rRNA standard. ASM News 65: 752-757.

Mora D.M., M.G. Fortina, G. Nicastro, C. Parini and P.L. Manachini. 1998. Genotypic characterization of thermophilic bacilli: a study of new soil isolates and several reference strains. Res. Microbiol. 149: 711-722.

Namsaraev Z.B., O.B. Babasanova, Y.E. Dunaevsky, V.N Akimov, D.D Barkhutova, V.M. Gorlenko and B.B. Namsaraev. 2010. Anoxybacillus mongoliensis sp. nov., a novel thermophilic proteinase producing bacterium isolated from alkaline hot spring, central Mongolia. Microbiol. 79: 491-499.

Pikuta E., A. Lysenko, N. Chuvilskaya, U. Mendrock, H. Hippe, N. Suzina, D. Nikitin, G. Osipov and K. Laurinavichius. 2000. Anoxybacillus pushchinensis gen. nov., sp. nov., a novel anaerobic, alkaliphilic, moderately thermophilic bacterium from manure, and description of Anoxybacillus flavithermus comb. nov. Int. J. Syst. Evol. Microbiol. 50: 2109-2117.

Pikuta E., D. Cleland and J. Tang 2003. Aerobic growth of Anoxybacillus pushchinoensis $\mathrm{K}^{\mathrm{T}}$ : emended descriptions of $A$. pushchinoensis and the genus Anoxybacillus. Int. J. Syst. Evol. Microbiol. 53: 1561-1562. 
Poli A., E. Esposito, L. Lama, P. Orlando, G. Nicolaus, F. De Appolonia, A. Gambacorta and B. Nicolaus. 2006. Anoxybacillus amylolyticus sp. nov., a thermophilic amylase producing bacterium isolated from Mount Rittmann (Antarctica). Syst. Appl. Microbiol. 29: 300-307.

Poli A., I. Romano, P. Cordella, P. Orlando, B. Nicolaus and C.C. Berrini. 2009. Anoxybacillus thermarum sp. nov., a novel thermophilic bacterium isolated from thermal mud in Euganean hot springs, Abano Terme, Italy. Extremophiles. 13: 867-874.

Rodas A.M, S. Ferrer and I. Pardo. 2003. 16S-ARDRA, a tool for identification of lactic acid bacteria isolated from grape must and wine. Syst. Appl. Microbiol. 26: 412-422.

Rosselló-Mora R. 2005. Updating prokaryotic taxonomy. J. Bacteriol. 187: 6255-6257.

Saitou N. and M. Nei. 1987. The neighbor-joining method: A new method for reconstructing phylogenetic trees. Mol. Biol. Evol. 4: 406-425.

Schäffer C., W.L. Franck, A. Scheberl, P. Kosma, T.R. Mcdermott and P. Messner. 2004. Classification of isolates from locations in Austria and Yellowstone National Park as Geobacillus tepidamans sp. nov. Int. J. Syst. Evol. Microbiol. 54: 2361-2368.

Stackebrandt E. and B.M. Goebel. 1994. Taxonomic note: A place for DNA-DNA reassociation and 16S rRNA sequence analysis in the present species definition in bacteriology. Int. J. System. Bacteriol. 44: 846-849.

Stackebrandt E., W. Fredericksen G.M. Garrity, P.A.D. Grimont, P. Kämpfer, M.C.J. Maiden, X. Nesme, R. Rossello-Mora, J. Swings, H.G. Trüper, L. Vauterin, A.C. Ward and W.B. Whitman. 2002. Report of the ad hoc committee for the re-evaluation of the species definition in bacteriology. Int. J. Syst. Evol. Microbiol. 52: 1043-1047.
Suzuki Y., T. Kishigami and S. Abe. 1976. Production of extracellular a-glucosidase by a thermophilic Bacillus species. Appl. Environ. Microbiol. 31: 807-812.

Tamura K., J. Dudley, M. Nei and S. Kumar. 2007. MEGA4: Molecular Evolutionary Genetics Analysis (MEGA) software version 4.0. Mol.Biol. Evol. 24: 1596-1599.

Tekin N., A.C. Cihan, Z.S. Takac, C.Y. Tuzun, K. Tunc and C. Cokmus. 2012. Alkaline protease production of Bacillus cohnii APT5. Turk. J. Biol. 36: 430-440.

Vaneechoutte M., R. Rossau, P. De Vos, M. Gills, D. Janssens, N. Paepe, A. De Rouck, T. Fiers, G. Claeys and K. Kersters. 1992 Rapid identification of bacteria of the Comamonadaceae with amplified ribosomal DNA-restriction analysis (ARDRA). FEMS Microbiol. Letts. 93: 227-234.

Versalovic J., M. Schneider, F.J. De Bruijn and J.R. Lupski. 1994. Genomic fingerprinting of bacteria using repetitive sequence based PCR (rep-PCR). Meth. Cell. Mol. Biol. 5: 25-40.

White D., R.J. Sharp and F.G. Priest. 1993. A polyphasic taxonomic study of thermophilic bacilli from a wide geographical area. Antonie van Leeuwenhoek. 64: 357-386.

Yumoto I., K. Hirota, T. Kawahara, Y. Nodasaka, H. Okuyama, H. Matsuyama, Y. Yokota, K. Nakajima and T. Hoshino. 2004. Anoxybacillus voinovskiensis sp. nov., a moderately thermophilic bacterium from a hot spring in Kamchatka. Int. J. Syst. Evol. Microbiol. 54: 1239-1242.

Zhang C.M., X.W. Huang, W.Z. Pan, J. Zhang, K.B. Wei, H.P. Klenk, S.K. Tang, W.J. Li and K.Q. Zhang. 2010. Anoxybacillus tengchongensis sp. nov. and Anoxybacillus eryuanensis sp. nov., two novel facultatively anaerobic, alkalitolerant bacteria from hot springs in Yunnan, China. Int. J. Syst. Evol. Microbiol. 61: 118-122. 
